\title{
Survey of Tea (Camellia Sinensis L.) Insect Pests in Southwest Ethiopia
}

\author{
Sisay Kidanu*, Wakjira Getachew, Tamiru Shimelis, Mohammedsani Zakir \\ Ethiopian Institute of Agricultural Research, Jimma Research Center, P. O. Box 192, Jimma, Ethiopia \\ *Corresponding Authors: Sisay Kidanu, Ethiopian Institute of Agricultural Research, Jimma Research \\ Center, P. O. Box 192, Jimma, Ethiopia
}

\begin{abstract}
Tea is a perennial crop, grown as a monoculture and one of the most popular beverages. The objectives of the study were to collect, identify and prioritize major insect pest species that constrain tea production in the Southwest. Wushwush, Gumaro, and East Africa and their surrounding tea out grower's farms were considered in the survey and assessed from 77 tea farms. Different insect pests were observed feeding various plant parts of tea in field. Among them, tea aphid and termite were considered as major pests. The percent of farm infestation of aphids was $85 \%$ at East Africa, 40\% at Gumaro, 50\% at Jimma research center. Most of the minor insect pests of tea were recorded from various farms. There was highly significant $(p<0.001)$ variation in access to crop protection training among farmers and only $31.2 \%$ of them took training. Generally, there were variations of species and infestation of insect pests'between and within tea plantations. Although most of the insects recorded during the study period have been considered as minor, it is not unlikely that any one of the minor pests may attain the status of major pests depending upon the environmental conditions. Therefore, the present findings calls regular monitoring of tea gardens in different ecological range and it could also provide good knowledge of all prevailing pest problems.
\end{abstract}

Keywords: infested farm, out growers, tea plantation

\section{INTRODUCTION}

Tea (Camellia sinensis (L.) O. Kuntze) is one of the most popular and lowest cost beverages in the world, and consumed by a wide range of age groups in all levels of society with more than three billion cups daily worldwide (Hick, 2009; Phong et al., 2016). Majority of the tea producing countries are located in the continent of Asia where China, India, Sri Lanka are the major producers. African tea growing countries are located mostly around the tropical regions where Kenya, Malawi, Rwanda, Tanzania, Uganda are major producers. In terms of area under tea plantation, on an average during the last two decade (1991 - 2010), China lead $(45 \%)$ the world followed by India (21\%), Sri Lanka (7\%), Kenya (5\%), Vietnam (3\%) (Basu et al, 2012). The tea plant is a small evergreen, perennial and develops normally as tall as $15 \mathrm{~m}$. However, under cultivated conditions, a bush height of $60-100 \mathrm{~cm}$ kept for harvesting the tender leaves and the plant usually having an economic life span of 50-60 years (Mondal et al., 2004; Yemane et al., 2008).

Agricultural development is vital for sustainable growth and poverty reduction in Ethiopia. One of the key development challenges facing the country is: to manage its plant health, to maximize agricultural productivity, to address food security concerns, conserve natural resources, and generate rural income by participating fully in international trade of agricultural products. Tea is one of the most important cash crops of many countries including Ethiopia. As export diversification and import substitution program in the country, tea is one of the strategic crops with significant importance in the national economy, which has been given due emphasis by the government to intensify its production and productivity by subsistent farmers and large scale farming (EIAR, 2017).

Southwest Ethiopia where tea is being produced by large scale private farms and the nearby small scale tea out growers is highly suitable for tea production. Similarly, the environmental condition of Southwest Ethiopia is also highly suitable for continuous growth, multiplication and distribution of variety types of weeds (Tadesse et al., 1998), which are serving for alternate hosts for different tea insect pests. In Ethiopia tea is produced in mono-culture without shade trees and this condition 
enhance the multiplication and spread pests which require high eradiation for their proliferation and spread.

So far, no any insect pests' survey and documentation program has ever been done in tea producing areas of Ethiopia. Diversification of crop species, technology introductions and mono-cropping of commercial crops, inadequate quarantine measures along with the current global warming and the consequence climate change have contributed tremendously to the occurrence of new invasive insect species which kept on emerging almost regularly in the country. Invasive insects that emerged in the last two decades have become a threat to agriculture in general and in areas of tea production in particular causing huge economical and environmental losses in the country.

In order to address this challenge, the country must have a detailed knowledge of the health status of its crops. It was mandatory to have a capacity to document and access information on the biology, distribution, host range and economic status of endemic and emerging insect pests. Conducting periodic survey, documenting and monitoring of insect pests in tea production in the country and maintaining reference collections is a crucial step to developing insect pest management strategies for sustainable tea production in the country. Information on pest species incidence, severity, and abundance will help in assessing changing importance of different species in different seasons and situations, which in turn aid in identifying important species. In the 15 years strategic document of tea research established by the Ethiopian Institute of Agricultural Research periodic survey and documentation of major insect pests that was set as top priority short term plan, is believed to be the base for developing Integrated Pest Management (IPM) program and it is based on this document that this survey of insect pests of tea in south west Ethiopia is proposed. Therefore, the objectives of the study were to survey and prioritize major insect pest/s that constrain tea production in the Southwest tea production areas of the country.

\section{Materials ANd Methods}

\subsection{Descriptions of the Study Area}

The three big private tea farms Wushwush, Gumaro, and East Africa (Chewaka) and adequate number of tea out grower's farms were considered in the survey from two major tea growing regional states in Southwestern

Ethiopia. Wushwush Tea Plantation is endowed with ideal ecology for the production of good quality highland tea. Tea planting at Wushwush Plantation started as a trial in 1973 and till it reached itspresent size of 1249 hectares. It is located in Kaffa zone, Southern region460km Southwest of Addis Ababa, at altitudinal average $1900 \mathrm{~m}$ above sea level, rainfall is $1820 \mathrm{~mm}$ andthe minimum and maximum temperature is 12 and $24^{\circ} \mathrm{c}$ respectively. Its soil is fertile, good drainage, red browncolor and rich in organic matter (EthioAgri-ceft tea plantation, 2015). Gumaro tea plantation is located in Iluababora zone of Oromia region of Southwest Ethiopia at about $637 \mathrm{~km}$ fromthe capital, Addis Ababa.The present size of farm is 860 hectares. It is located at altitude of $1718 \mathrm{~m}$ above sea level and rainfall of $2089 \mathrm{~mm}$. The minimum and maximum temperature is 12 and $24^{\circ} \mathrm{c}$ respectively. Its soil is fertile, good drainage, red browncolor and rich in organic matter. In addition, Gumaro has 761 hectares of eucalyptus trees planted to serve as fuel for tea drying in the factories. Out growers are found around these plantation (Ethio Agri-ceft tea plantation, 2015). Chewaka Tea Estate, (now called East African Agribusiness) is a private company established in 1997, is located in the Southern Nation Nationalities and Peoples Representataives region of Sheka zonein Masha woreda some $650 \mathrm{~km}$ Southwest of Addis Ababa (Table 1). The estate has developed a tea plantation of 541 hectares and 210 ha of eucalyptus (Chewaka Tea Estate, 2009).

Table1. Geographical information of the surveyed tea plantations in Southwest of Ethiopia

\begin{tabular}{|l|l|l|l|l|}
\hline Region/Zones/ & Districts & $\begin{array}{l}\text { Plantation/ } \\
\text { farms/Research field }\end{array}$ & $\begin{array}{l}\text { Altitude } \\
\text { (m asl) }\end{array}$ & $\begin{array}{l}\text { Farms/blocks } \\
\text { surveyed }\end{array}$ \\
\hline SNNPR /Kaffa/ & \multirow{2}{*}{ Gimbo } & Wushwush & $1771-1864$ & 20 \\
\cline { 3 - 5 } & & $\begin{array}{l}\text { Out-growers/ } \\
\text { Surrounding/ }\end{array}$ & $1766-1930$ & 20 \\
\hline SNNPR /Sheka/ & Masha & East Africa & $1743-1808$ & 10 \\
\cline { 3 - 5 } & $\begin{array}{l}\text { Out-growers } \\
\text { /Surrounding/ }\end{array}$ & $1720-1750$ & 05 \\
\hline
\end{tabular}




\begin{tabular}{|l|l|l|l|l|}
\hline Oromia/Iluababora/ & Ale/Gore & Gemadro & $1663-1746$ & 10 \\
\cline { 3 - 5 } & $\begin{array}{l}\text { Out-growers } \\
\text { /Surrounding/ }\end{array}$ & $1627-1741$ & 10 \\
\hline Oromia/Jimma/ & $\begin{array}{l}\text { Jimma/ } \\
\text { Melko }\end{array}$ & Research farm & 1747,1761 & 02 \\
\hline
\end{tabular}

SNNPR= Southern Nation, Nationality and Peoples Representatives

\subsection{Sampling Procedure}

The survey was conducted in October 2018 and June 2019 in the three big tea plantations and out grower farmers around plantation (garden). Totally 77 tea farms were assessed for insect pest infestation. A three phase sampling techniques were used to select sample tea producing fields/blocks for the assessment of insect pests. In the first phase from each selected big tea farms, three representativeblocks/farms were selected. In the second phase, three sites from each block were selected. In the third stage, five tea spotes $\left(5-10 \mathrm{~m}^{2}\right)$ from each site wereassigned based on their field management practices, production system and variety. From each tea spots 10 randomly selected tea bushes were used for data collection. Other necessary information were gathered through direct field observation and questionnaires were used during the survey to gather information about insect data, field agronomic practices, farmers pest perception and farmer's pest management practices.

\subsection{Data Collection}

Insects feeding on tea plants (larvae, pupae, adults) in the fields were recorded and documented. For fly insects sweep net was used during the survey. Insect specimens in the field were identified using the available insects colored pictured identification guides. Collection of quantitative data was carried outusing a structured data sheet for each tea field.

$$
\begin{gathered}
\text { Percent of farm infested }=\underline{\text { Number of infested farm }} * 100 \\
\text { Total number of surveyed farms }
\end{gathered}
$$

\subsection{Data Analysis}

All data collected from survey was summarized on excel spreadsheet and analyzed through descriptive statistics, to generate summaries and tables at different levels using Statistical Package for Social Sciences (SPSS, 1996 Ver. 20). Comparative statistical tools including chi square were used to compare the different socio-demographic, farm characteristics, and knowledge on tea insect pests and pest management practices of farmers across the surveyed districts. Means of farm infestations were calculated for frequently recorded insect pests.

\section{RESULT AND DiSCUSSION}

\subsection{Socio-Demographic Characteristics of Tea Farms}

During the survey about $42.9 \%$ of the assessed fields were from plantation of the surrounding tea outgrowers (garden) where as $57.1 \%$ of them were from the three big tea plantations (Annex 1). In the Southwestern of the country farmers practice tea productions for different purposes. All the surveyed farms cropping system was sole and $72 \%$ of them produce tea for marketing purpose only and about $24 \%$ is for both market and conservation for planting material, where only $2.6 \%$ is for conservation only (Table 2).There was a highly significant difference $(\mathrm{p} \leq 0.001)$ in use tea harvesting or plucking methods across the farmers. The majorities $(75.3 \%)$ of the interviewed farmers were using manual hand plucking method for tea harvesting and only $5.2 \%$ were used machine harvestors, which is practiced in the big plantations. But, about $19.5 \%$ of them were used both manually plucking and machine harvestors (Table 2).

\begin{tabular}{|c|c|c|c|c|c|c|c|c|}
\hline \multirow[b]{2}{*}{ Variables } & \multicolumn{6}{|c|}{ Tea plantations } & \multirow[b]{2}{*}{$\begin{array}{l}\text { Mean } \\
(\%) \\
\end{array}$} & \multirow[b]{2}{*}{$\chi^{2}$} \\
\hline & Wushwush & WushwushOutgrowers & $\begin{array}{c}\text { East } \\
\text { Africa }\end{array}$ & $\begin{array}{c}\text { East Africa } \\
\text { Outgrowers }\end{array}$ & Gumaro & $\begin{array}{c}\text { Gumero } \\
\text { Outgrowers }\end{array}$ & & \\
\hline $\begin{array}{l}\text { Purpose of } \\
\text { tea } \\
\text { production }\end{array}$ & & & & & & & & 49.61 *** \\
\hline Market & 6.5 & 26.0 & 11.7 & 6.5 & 16.9 & 9.1 & 76.6 & \\
\hline $\begin{array}{l}\text { Planting } \\
\text { material }\end{array}$ & 0.0 & 0.0 & 0.0 & 1.3 & 0.0 & 1.3 & 1.3 & \\
\hline
\end{tabular}

Table2.The purposes of tea production and method of harvesting of the respondents during the survey $(n=77)$ 
Survey of Tea (Camellia Sinensis L.) Insect Pests in Southwest Ethiopia

\begin{tabular}{|c|l|l|l|l|l|l|l|l|l|}
\hline $\begin{array}{l}\text { Market \& } \\
\text { planting }\end{array}$ & 19.5 & 0.0 & 1.3 & 0.0 & 1.3 & 0.0 & 22.1 & \\
\hline $\begin{array}{l}\text { Method of } \\
\text { tea } \\
\text { harvesting }\end{array}$ & \multicolumn{7}{l|l|}{} & \\
\hline Manually & 14.3 & 26.0 & 13.0 & 6.5 & 6.5 & 9.1 & 75.3 & \\
\hline Machine & 5.2 & 0.0 & 0.0 & 0.0 & 0.0 & 0.0 & 5.2 & \\
\hline Both & 6.5 & 0.0 & 0.0 & 0.0 & 13.0 & 0.0 & 19.5 & \\
\hline
\end{tabular}

Statistically significant $*$ at $p<0.05, * * p<0.01, * * * p<0.001 ; N S=$ not significant, $\chi 2=$ chi-square

There was highly significant $(\mathrm{p}<0.001)$ variations in the preference of tea clones used for planting across the assessed tea fields (Table 2). Majority of the tea producers (20\%) grew 11/4, BB/35 and $11 / 56$ clones and about $1.3 \%$ of them grew $12 / 38$ and $31 / 8$ clones (Table 3). Majority of Wushwush surrounding farmers $(15.6 \%)$ use $11 / 4$ tea clones as planting material and about $2.6 \%$ of both East Africa and its surrounding tea farmers use BB/35. On the other hand, 5.2 and $3.9 \%$ of Gumaro tea plantation assessed farms were produced $6 / 8$ and $11 / 56$ clones, but about 5.2 and $3.9 \%$ of its surrounding tea grower farmers were grew 11/56 and SR-18 clones respectively (Table 3).

Table 3 . Tea clones planted by big plantations and their surrounding farmers $(n=77)$

\begin{tabular}{|c|c|c|c|c|c|c|c|c|}
\hline \multirow[b]{2}{*}{ Variables } & \multicolumn{6}{|c|}{ Tea plantations } & \multirow[b]{2}{*}{$\begin{array}{c}\text { Mean } \\
(\%)\end{array}$} & \multirow[b]{2}{*}{$\chi^{2}$} \\
\hline & $\begin{array}{c}\text { Wushwvus } \\
\mathrm{h}\end{array}$ & $\begin{array}{l}\text { Wushwush } \\
\text { Outgrowers }\end{array}$ & $\begin{array}{l}\text { East } \\
\text { Africa }\end{array}$ & $\begin{array}{l}\text { East Africa } \\
\text { Outgrowers }\end{array}$ & $\begin{array}{l}\text { Gum } \\
\text { aro }\end{array}$ & $\begin{array}{c}\text { Gumero } \\
\text { Outgrowers }\end{array}$ & & \\
\hline Tea clones & & & & & & & & $91.96^{* * *}$ \\
\hline $11 / 4$ & 5.2 & 15.6 & 0.0 & 0.0 & 0.0 & 0.0 & 20.8 & \\
\hline $\mathrm{BB} / 35$ & 7.8 & 3.9 & 2.6 & 2.6 & 2.6 & 0.0 & 19.5 & \\
\hline $6 / 8$ & 5.2 & 2.6 & 0.0 & 1.3 & 5.2 & 0.0 & 14.3 & \\
\hline $11 / 56$ & 5.2 & 0.0 & 3.9 & 1.3 & 3.9 & 5.2 & 19.5 & \\
\hline $12 / 38$ & 1.3 & 0.0 & 0.0 & 0.0 & 0.0 & 0.0 & 1.3 & \\
\hline $31 / 8$ & 0.0 & 0.0 & 0.0 & 1.3 & 0.0 & 0.0 & 1.3 & \\
\hline SR-18 & 0.0 & 0.0 & 0.0 & 0.0 & 1.3 & 3.9 & 5.2 & \\
\hline Mixed & 1.3 & 3.9 & 6.5 & 0.0 & 6.5 & 0.0 & 18.2 & \\
\hline
\end{tabular}

The majority (66.2\%) of the interviewed tea farmers were applied both DAP and UREA fertilizer and about $3.9 \%$ of the farmers use compost, DAP and UREA for their tea production in southwest Ethiopia. There was highly significant $(\mathrm{p}<0.001)$ variation in application of compost and chemical fertilizer across tea plantation and farmers. Only $1.3 \%$ of the farms were applied compost which used by Wushwush plantation (Table 4).

Most of the interviewed farmers did not have opportunity forpests'management training except 31.2 $\%$ of them (most of Gumaro and few of Wushwush and their surroundings tea farmers) were got access for crop protection training (Table 4).

Table 4. Fertilizer application and crop protection training access for tea producers $(n=77)$

\begin{tabular}{|c|c|c|c|c|c|c|c|c|}
\hline \multirow[b]{2}{*}{ Variables } & \multicolumn{6}{|c|}{ Tea plantations } & \multirow[b]{2}{*}{\begin{tabular}{l|l} 
Mean & \\
$(\%)$ &
\end{tabular}} & \multirow[b]{2}{*}{$\chi^{2}$} \\
\hline & $\begin{array}{c}\text { Wushwu } \\
\text { sh }\end{array}$ & $\begin{array}{l}\text { Wushwush } \\
\text { Outgrowers }\end{array}$ & $\begin{array}{c}\text { East } \\
\text { Africa }\end{array}$ & $\begin{array}{l}\text { East Africa } \\
\text { Outgrowers }\end{array}$ & Gumaro & $\begin{array}{c}\text { Gumero } \\
\text { Outgrowers }\end{array}$ & & \\
\hline $\begin{array}{l}\text { Fertilizers } \\
\text { used }\end{array}$ & & & & & & & & $41.51^{* * *}$ \\
\hline Compost & 1.3 & 0.0 & 0.0 & 0.0 & 0.0 & 0.0 & 1.3 & \\
\hline $\mathrm{DAP}$ & 3.9 & 0.0 & 0.0 & 0.0 & 0.0 & 0.0 & 3.9 & \\
\hline UREA & 13.0 & 7.8 & 1.3 & 0.0 & 1.3 & 1.3 & 24.7 & \\
\hline $\begin{array}{l}\text { DAP\& } \\
\text { UREA }\end{array}$ & 3.9 & 18.2 & 11.7 & 6.5 & 18.2 & 7.8 & 66.2 & \\
\hline All & 3.9 & 0.0 & 0.0 & 0.0 & 0.0 & 0.0 & 3.9 & \\
\hline $\begin{array}{l}\text { Training on } \\
\text { protection }\end{array}$ & & & & & & & & $39.56^{* * * *}$ \\
\hline Yes & 3.9 & 3.9 & 0.0 & 0.0 & 14.3 & 9.1 & 31.2 & \\
\hline No & 22.1 & 22.1 & 13.0 & 6.5 & 5.2 & 0.0 & 68.8 & \\
\hline
\end{tabular}




\subsection{Insect Pests Observed in Tea Fields During the Survey}

Most parts of the study area were characterized modern intensive tea plantation and the out-growers or local tea farmers. Different insect pests were observed feeding tea different plant parts in field. Tea aphid, termite, flea beetle, red ant, serpentine leaf miner, tea leaf skeletonizer, soft brown scale, orange scale, metallic leaf beetles, grasshoppers were among frequently recorded during the survey (Table 5). From these tea aphids and termite were considered as the major insect pests of tea while the rests were of miner importance on the basis of nature and type of damage and infestations (Fig. 1). Different insect pests were observed in tea fields of Southwestern of Ethiopia and aphid was one of the major pests of tea causing infestation on leaves at in the field and on young seedlings at nursery (Mohammedsani, 2017; Esayas, 2006 unpublished). According to Mamun and Ahmed (2011) aphids, termite, thrips, scales and spider mite were the major insect pests of tea recorded in Bangladish.

In tea production of Southwestern part of Ethiopia, most of the insect pests of tea are of minor importance except tea aphids and termite, as opposed to many tea producing countries. One of the possible reasons is the probabilities for existence of diverse natural enemy communities, which keep the population at a low level mainly in the relatively undisturbed tea plantation ecosystems, where pest and natural enemy balance is maintained. Nevertheless, if there are any adverse agronomic/ farm practices that affect the natural biological balance between pest and their natural enemies, these minor pests can pose a serious problem to tea production. According to Tsedeke (1988) many insect pests of tea were reported on tea, even though all of them have minor importance except the aphid which is the major pest of young leaves of tea seedlings.

Table5. Lists of insect pests of tea, plant parts they damage and farms frequently recorded

\begin{tabular}{|l|l|l|l|l|}
\hline $\begin{array}{l}\text { Common } \\
\text { name }\end{array}$ & Order & Family & Scientific name & $\begin{array}{l}\text { Plant part } \\
\text { attached }\end{array}$ \\
\hline Tea aphid & Homoptera & Aphididae & Toxopteraaurantii(Boyer de Fonsc.) & Leaf \& bud \\
\hline Termite & Isoptera & Termitidae & Microtermes obesi,Holmgren & Stem \& root \\
\hline $\begin{array}{l}\text { Metallic } \\
\text { leaf beetle }\end{array}$ & Coleopetra & Lagridae & LagriavillosaFabricius & Leaf eater \\
\hline Red Ant & Hymenoptera & Formicidae & Oecophyllaspp & Bud \& leaf \\
\hline $\begin{array}{l}\text { Soft brown } \\
\text { scale }\end{array}$ & Heteroptera & Coccidae & Coccushesperidum $($ L.) & Leaf \& stem \\
\hline $\begin{array}{l}\text { Orange } \\
\text { scale }\end{array}$ & Heteroptera & Diaspidae & Chrysomphalusdictyospermi(Morgan) & Leaf \& stem \\
\hline $\begin{array}{l}\text { Tea } \\
\text { grasshopper }\end{array}$ & Orthoptera & Acrididae & CatantopsmelanostictusSchaum & Leaf \\
\hline
\end{tabular}

The percent of infested farms by these insect pests of tea in the Southwest of Ethiopia varies of from farm to farm as well as from plantation to plantation. Among the major pests, tea aphid percent of infested tea farms were high except at Wushwush plantation. The infested percent was $85 \%$ at East Africa and its surrounding farmers, $40 \%$ at Gumaro and its surrounding farmers, $50 \%$ at Jimma research center (Melko) and 10\% at Wushwush plantations (Fig.2 and 3). Most of the minor insect pests of tea were recorded from various farms during the survey. Flea beetle was infested higher percent at Wushwush and East Africa plantation (45\%). Red ant was also recorded seriously at Wushwush (55\%) and Gumaro and its surrounding tea farms (50\%). On the other hand, about 25 and $100 \%$ of the assessed tea farms of East Africa and its surrounding were infested by the flea beetle and leaf miners such as leaf skeletonizer and serpentine) where as 60 and $40 \%$ at Gumaro including its surrounding respectively (Fig. 2 and 3).

One of the basic requirements of pest control is the economic threshold levels (ETL) at which control measures are justified. In Bangladish it was also reported that the economic threshold level of aphids and termite were 20 and $10 \%$ infestation respectively (Mamun and Ahmed, 2011). 


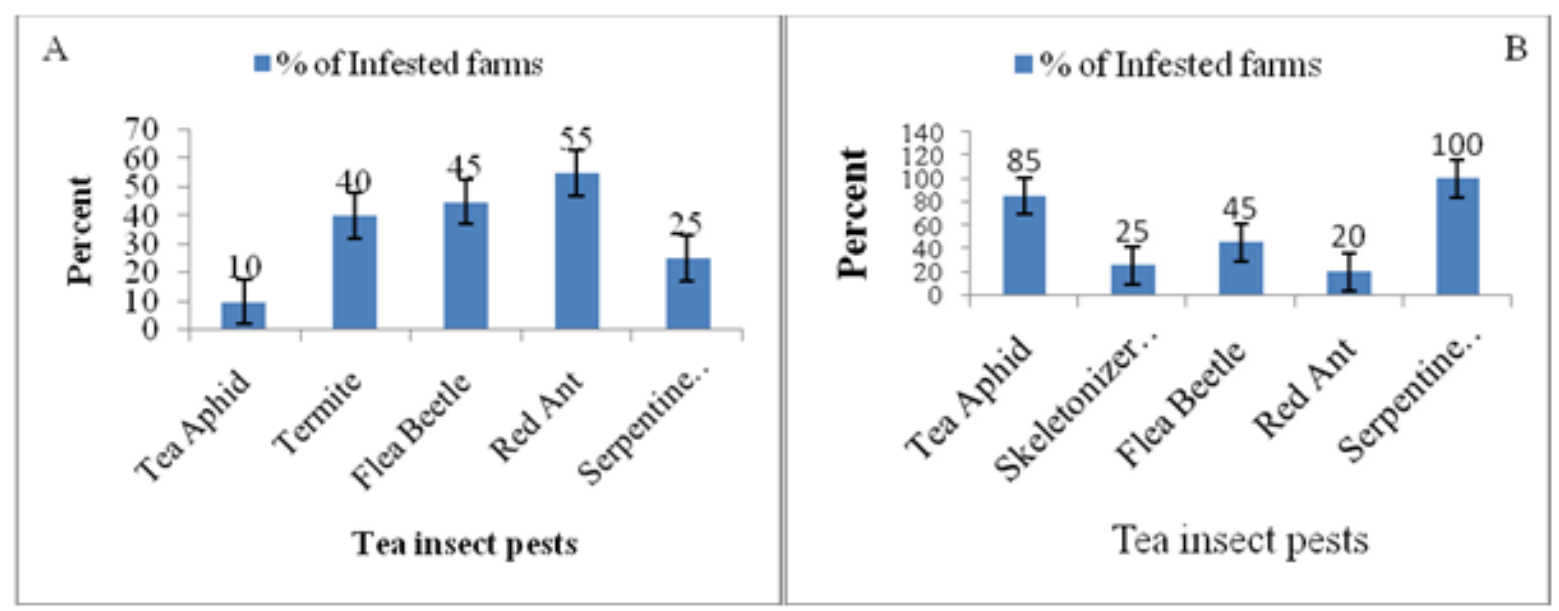

Fig. 2. Farm infested percent at Wushwush (A) and East Africa including their out-growers (B)

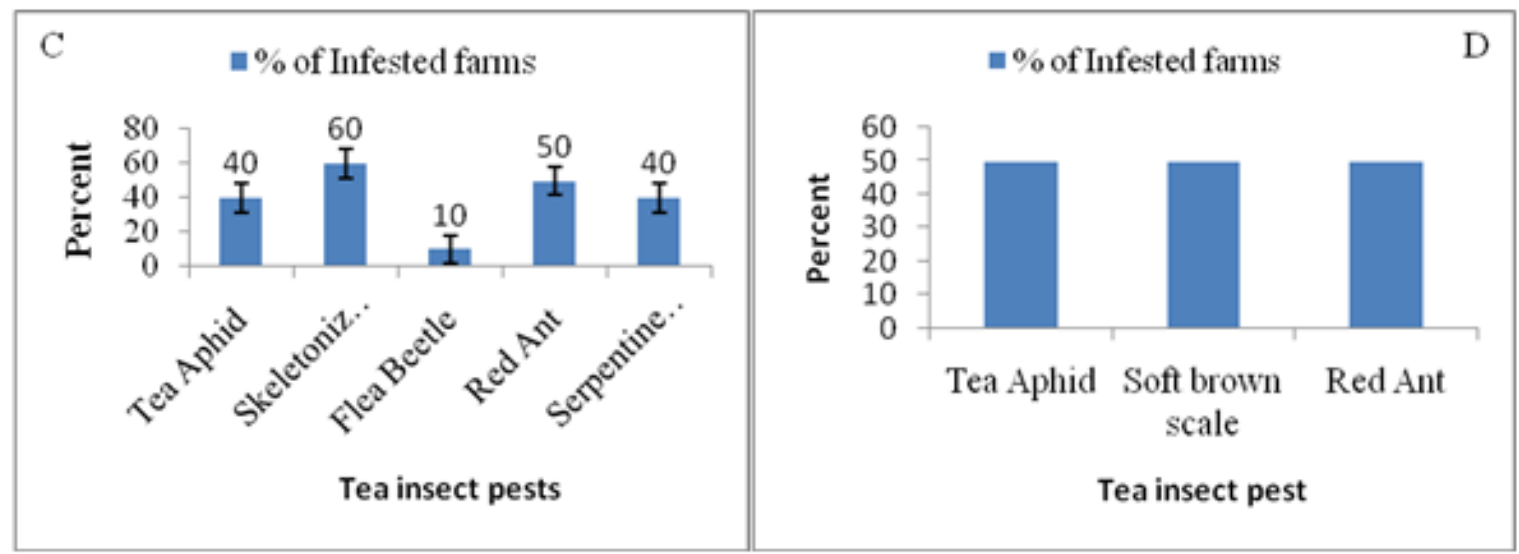

Fig. 3. Farm infested percent by different insect pests at Gumaro+outgrowers(C) and Melko (D)

\section{CONCLuSion}

Various insect pests were observed feeding tea different plant parts. Tea aphid, termite, flea beetle, red ant, serpentine leaf miner, leaf skeletonizer, soft brown scale, orange scale, metallic leaf beetles, grasshoppers were among the recorded pests during the survey. Although most of the insects recorded during the study period have been considered as minor, it is not unlikely that any one of the minor pests may attain the status of major pests depending upon the environmental conditions. Therefore, the present study suggests that understanding the ecological roles of insect pests in the tea ecosystem and identifying major determinants of biotic and abiotic factors for their abundance are essential before applying any control option in tea plantations.

\section{ACKNOWLEDGEMENT}

Our thanks go to Ethiopian Institute of Agricultural Research (EIAR), Jimma Agricultural Research Center for their provision of logistics and vehicle during our survey work. We are grateful also to the Agronomists of Wushwush, Gumaro and East Africa tea plantation including their surrounding tea grower farmers, for their help during the whole survey works.

\section{REFERENCES}

[1] Basu MA, Bera B and Rajan A .2012. Tea Statistics: Global Scenario. Inc. J. Tea Sci. 8 (1): 121-124.

[2] Chewaka Tea Estate .2009. Strategic Plan, Addis Ababa.

[3] EIAR. 2017. National Tea Commodity Research Strategy; Ethiopian AgriculturalTransformation Agency. 9-42p.

[4] Ethio Agri-CEFT. 2015. Integrated farm development with environmentally sustainability in Ethiopia PLC.https://www.ethioagriceft.com/Tea.html

[5] Hick A. 2009. Current status and future development of global tea production and tea product.Assumpt, Univ. J. Technol., 12: 251-264 
[6] Jimma Agricultural Research Center, JARC. 2005. Coffee, Tea and Spice Division Progress Report for the period 2005 Melko, Ethiopia.

[7] Mamun MSA and Ahmed M. 2011. Integrated pest management in tea: prospects and futurestrategies in Bangladesh, The Journal of Plant Protection Sciences, 3(2): 1-13.

[8] Mohammedsani Z. 2017. Review on Tea (Camellia sinensis) Research Achievements, Challenges and Future Prospective Including Ethiopian Status ", International Journal of Forestry and Horticulture, 3(4): 27-39. http://dx.doi.org/10.20431/2454-9487.0304005

[9] Mondal TK, Bhattacharya A, Laxmikumaran M and Ahuja PS. 2004. Recent advances of tea (Camellia sinensis) biotechnology. Plant Cell, Tissue and Organ Culture 76: 195-254.

[10] Phong, N.H., W. Pongnak, K. Soytong, S. Poeaim, A. Poeaim, 2016. Diversity of tea (Camellia sinensis) grown in Vietnam based on morphological characteristics and inter-primer binding sites (iPBS) marker. Inter. Jour. of Agri. Bio., 18:385-392.

[11] Tadesse E, Bayissa M and Poulos D. 1998. Weed control in the western coffee growing areas of Ethiopia.pp22-27. In:BeyeneSeboka and AberaDeressa.(eds). Agricultural Research and Technology Transfer Attempts and Achievements in western Ethiopia. Proceedings of the third Technology Generation, Transfer and Gap Analysis Workshop, 12-14 November1996, Nekemte, Ethiopia.

[12] Tsedeke A. 1988. Insect and mite pests of horticultural and miscellaneous plants in Ethiopia. IAR Handbook No. 1, IAR, Addis Ababa, Ethiopia, 115 pp.

[13] Yemane, M., B.S. Chandravanshi, T. Wondimu, 2008. Levels of essential and non-essentialmetals in leaves of the tea plant (Camellia sinensis L.) and soil of Wushwush farms, Ethiopia, Food Chem., 107:1236-1243.

Annex 1. Coverage of tea farms in the big plantation and gardens (surrounding farmers)

\begin{tabular}{|l|l|l|l|l|l|l|l|l|}
\hline \multirow{2}{*}{\begin{tabular}{l} 
Variable \\
\cline { 2 - 9 }
\end{tabular}} & $\begin{array}{c}\text { Wushw } \\
\text { ush }\end{array}$ & $\begin{array}{c}\text { WushwushOutgr } \\
\text { owers }\end{array}$ & $\begin{array}{c}\text { East } \\
\text { Afri } \\
\text { ca }\end{array}$ & $\begin{array}{c}\text { East } \\
\text { africaOutgro } \\
\text { wers }\end{array}$ & $\begin{array}{c}\text { Guma } \\
\text { ro }\end{array}$ & $\begin{array}{c}\text { GumeroOutgro } \\
\text { wers }\end{array}$ & $\begin{array}{l}\text { Mea } \\
(\%)\end{array}$ & $\chi^{2}$ \\
\hline $\begin{array}{l}\text { Producti } \\
\text { on } \\
\text { system }\end{array}$ & & & & & & & & $\begin{array}{l}7 \\
* *\end{array}$ \\
\hline Garden & 0.0 & 26.0 & 1.3 & 6.5 & 0.0 & 9.1 & 42.9 & \\
\hline $\begin{array}{l}\text { Plantatio } \\
\mathrm{n}\end{array}$ & 26.0 & 0.0 & 11.7 & 0.0 & 19.5 & 0.0 & 57.1 & \\
\hline
\end{tabular}

Annex 2. Tea clones assessed during the survey and their descriptions

\begin{tabular}{|l|l|l|l|}
\hline $\begin{array}{l}\text { Serial } \\
\text { no. }\end{array}$ & Country of introduction & Tea clones & Source of tea clones \\
\hline 1 & Kenya & $11 / 56$ & Wushwush \\
\hline 2 & India & BB-35 & Gummaro \\
\hline 3 & India & SR-18 & Gummaro \\
\hline 4 & Kenya & $11 / 4$ & Wushwush \\
\hline 5 & Kenya & $6 / 8$ & Wushwush \\
\hline
\end{tabular}

Source: Jimma Agricultural Research Center (JARC, 2005)

Citation: Sisay Kidanu,et.al., "Survey of Tea (Camellia Sinensis L.) Insect Pests in Southwest Ethiopia." International Journal of Research Studies in Agricultural Sciences (IJRSAS), 2020; 6(10), pp. 23-29, https://doi.org/10.20431/2454-6224.0610003

Copyright: ( $\odot 2020$ Authors. This is an open-access article distributed under the terms of the Creative Commons Attribution License, which permits unrestricted use, distribution, and reproduction in any medium, provided the original author and source are credited. 